\title{
USE OF THE COASTAL ZONE COLOR SCANNER FOR EQPAC PLANNING
}

\author{
By Gene C. Feldman, James W. Murray and Margaret W. Leinen
}

\section{$\mathrm{O}$} NE OF THE MOST INTERESTING and useful pieces of data for basin-scale planning of EqPac (Leinen and Murray, 1990; Murray et al., 1992, this issue) was the satellite-derived ocean-color data set acquired by the Coastal Zone Color Scanner (CZCS) (Feldman et al., 1989). To accomplish EqPac goals we need a more precise estimate of the temporal and spatial distributions of phytoplankton biomass and primary production. Traditional shipboard sampling techniques by themselves are not sufficient to meet these needs on global, or for that matter, basin scales. However, satellite observations of ocean color can provide reliable estimates of marine phytoplankton biomass at the relevant time and space scales.

The United States-Joint Global Ocean Flux Study (US-JGOFS) is relying heavily on satellite ocean-color data for large-scale planning activities, for real-time cruise support, and for global diagnostic and prognostic modelling efforts. Currently, only the retrospective CZCS data set acquired between November 1978 and June 1986 is available. However, Sea Viewing Wide Field Sensor (SeaWiFS), an ocean-color sensor that is planned for launch in late 1993, will be a key to biogeochemical studies including the US-JGOFS Indian Ocean Process Study in 1994/95. Future work can be more quantitative because global coverage will be obtained every two days and real-time data from ships and moorings can be used for calibration. During the Equatorial Pacific Process Study (EqPac) in 1992, there will be no ocean-color satellite in orbit and instead there will be overflights by the National Atmospheric and Space Administration (NASA) long-range P3B aircraft. Otherwise, at present we only have the historical CZCS data set, but that has proved to be quite useful.

G.C. Feldman, National Atmospheric and Space Administration, Goddard Space Flight Center. Code 636. Greenbelt, MD 20771 USA. J.W. Murray, School of Oceanography, University of Washington, Seattle. WA 98195 USA. M.W. Leinen, Graduate School of Oceanography, University of Rhode Island, Narragansett, RI 02882-1 197 USA.
Variability in the optical properties of the open ocean is determined to a great extent by the distribution and abundance of phytoplankton and their associated pigments. The changes in ocean color detected by the CZCS provide a quantitative measure of near-surface phytoplankton pigment, which for remote sensing applications represent the sum of chlorophyll a and phaeophytin a concentrations (Gordon and Morel, 1983). These estimates are an index of phytoplankton biomass, and with the appropriate ancillary information may be empirically related to primary production. The depth to which the satellite-derived oceancolor measurements apply is inversely related to the concentration of phytoplankton and suspended material in the water column. The CZCSderived values represent the average pigment concentration to a depth of one optical attenuation length ( $\sim$ the top $20-30 \%$ of the euphotic zone), which for pigment concentrations typical of the Equatorial Pacific may be as deep as 20$30 \mathrm{~m}$.

A $7 \frac{1}{2}$-yr composite image of surface phytoplankton pigment (hereafter referred to as the CZCS climatology) for the Pacific Basin is shown on the cover of this issue. There were some seasonal and temporal biases in the original data, thus the image shown is a composite, not a mean. In addition to providing a visual representation of the phytoplankton biomass, the satellite image can be used to produce hypothetical sections that a ship may see. Because the composite is for a several year period, these sections represent a reference climatology. The data from a specific cruise will be different in detail but should observe the same large-scale patterns.

The composite CZCS image of the Pacific Ocean clearly shows a region of enhanced phytoplankton pigment concentrations along the equator extending from the South American coast to $\sim 170^{\circ} \mathrm{E}$. The band of highest pigment concentrations $\left(0.15 \mathrm{mg} \mathrm{m}^{-3}\right)$ appears relatively symmetrical about the equator, and is $\sim 400 \mathrm{~km}$ in width. Analyses of the global CZCS composites show that this equatorial band of high pigment
... US-JGOFS is

relying heavily on satellite ocean-color data for ... planning activities. 


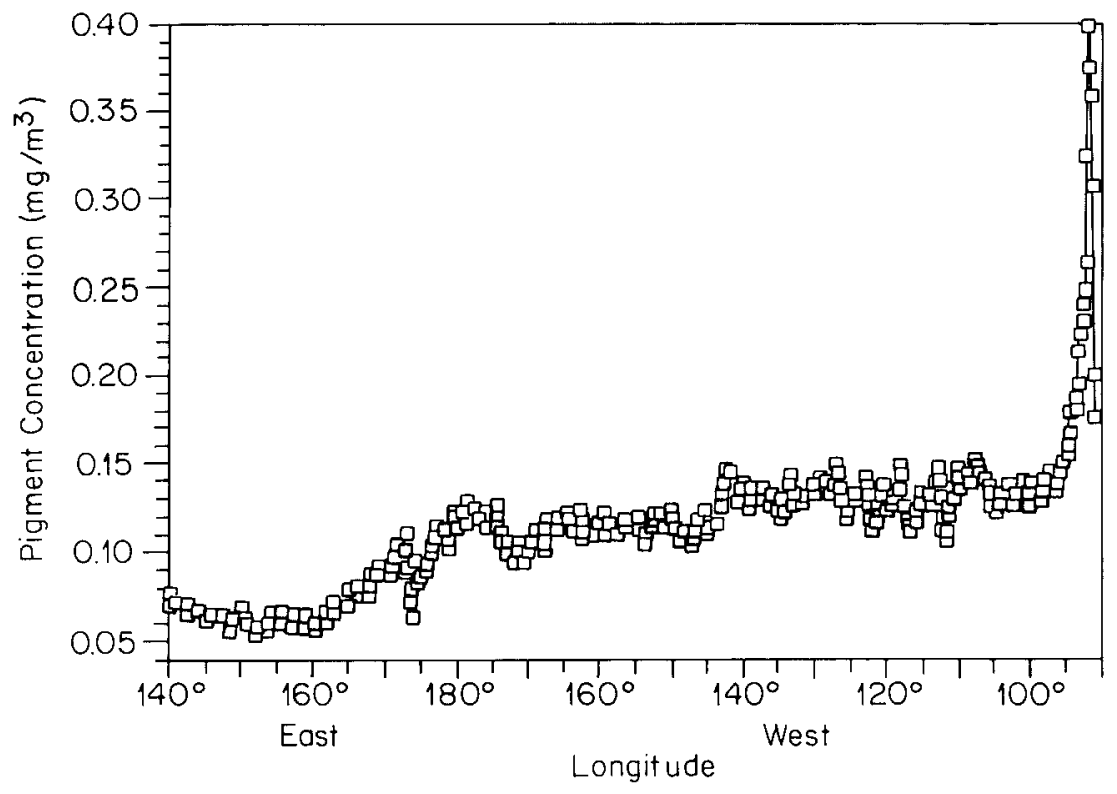

Fig. 1: Hypothetical section of satellite-derived total pigment along the equatorial Pacific from $140^{\circ} \mathrm{E}$ to $90^{\circ} \mathrm{W}$. This section was produced from the climatological data set covering boreal fall 1978 to boreal spring 1986. The horizontal distance between samples is one pixel $(\sim 18.5 \mathrm{~km}$ resolution at the equator).

... this equatorial

band of high pigment

concentration is one of the dominant features of the global ocean. concentration is one of the dominant features of the global ocean. One of the important sources of variability in the near-equatorial region are trop-

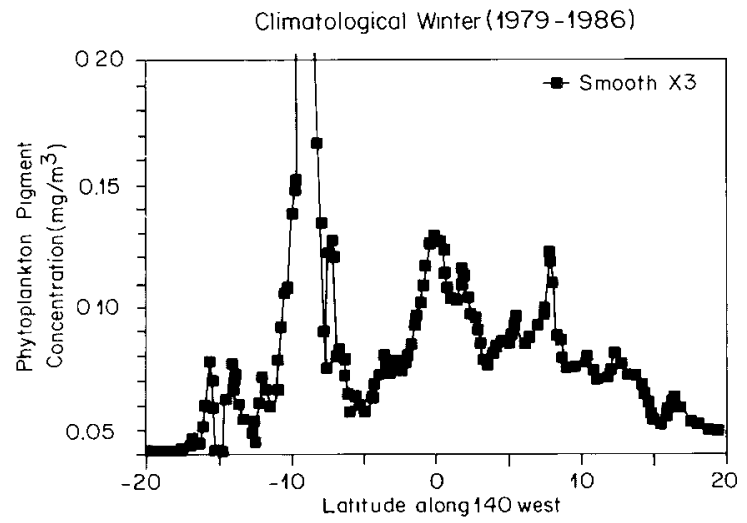

ical instability waves with periods of 22 to 25 days. The biological signature of these waves can be clearly seen in either the individual (daily), or short-term-average CZCS images (Feldman, 1985).

The equatorial Pacific zonal production sections of Chavez and Barber (1987) suggest that a north-south transect located anywhere from $110^{\circ}$ to $150^{\circ} \mathrm{W}$ would sample a similar productivity regime. The CZCS-pigment imagery supports this idea. The station locations for the National Science Foundation (NSF) component of EqPac were chosen to be at $140^{\circ} \mathrm{W}$ where the currents are highly zonal (east-west), the physical circulation constrained by the Equatorial Pacific Ocean Climate Study/Tropical Ocean Global Atmosphere Tropical Atmosphere Ocean (EPOCS/TOGA TAO) array, and productivity is high.

The hypothetical data section along the equator from $140^{\circ} \mathrm{E}$ to $90^{\circ} \mathrm{W}$ derived from the CZCS climatology is shown in Figure 1. Total pigment is low in the west at $\sim 0.06 \mathrm{mg} \mathrm{m}^{-3}$, and increases to $\sim 0.12 \mathrm{mg} \mathrm{m}^{-3}$ near the dateline. Total pigment stays fairly constant for the remainder of that transect until the Galapagos region at $\sim 90^{\circ} \mathrm{W}$ (Feldman, 1986). It is difficult to make a direct comparison between the CZCS climatology-inferred concentrations and those actually measured because of the lack of sufficient ship-board data. Based on the data available, the large-scale pat-
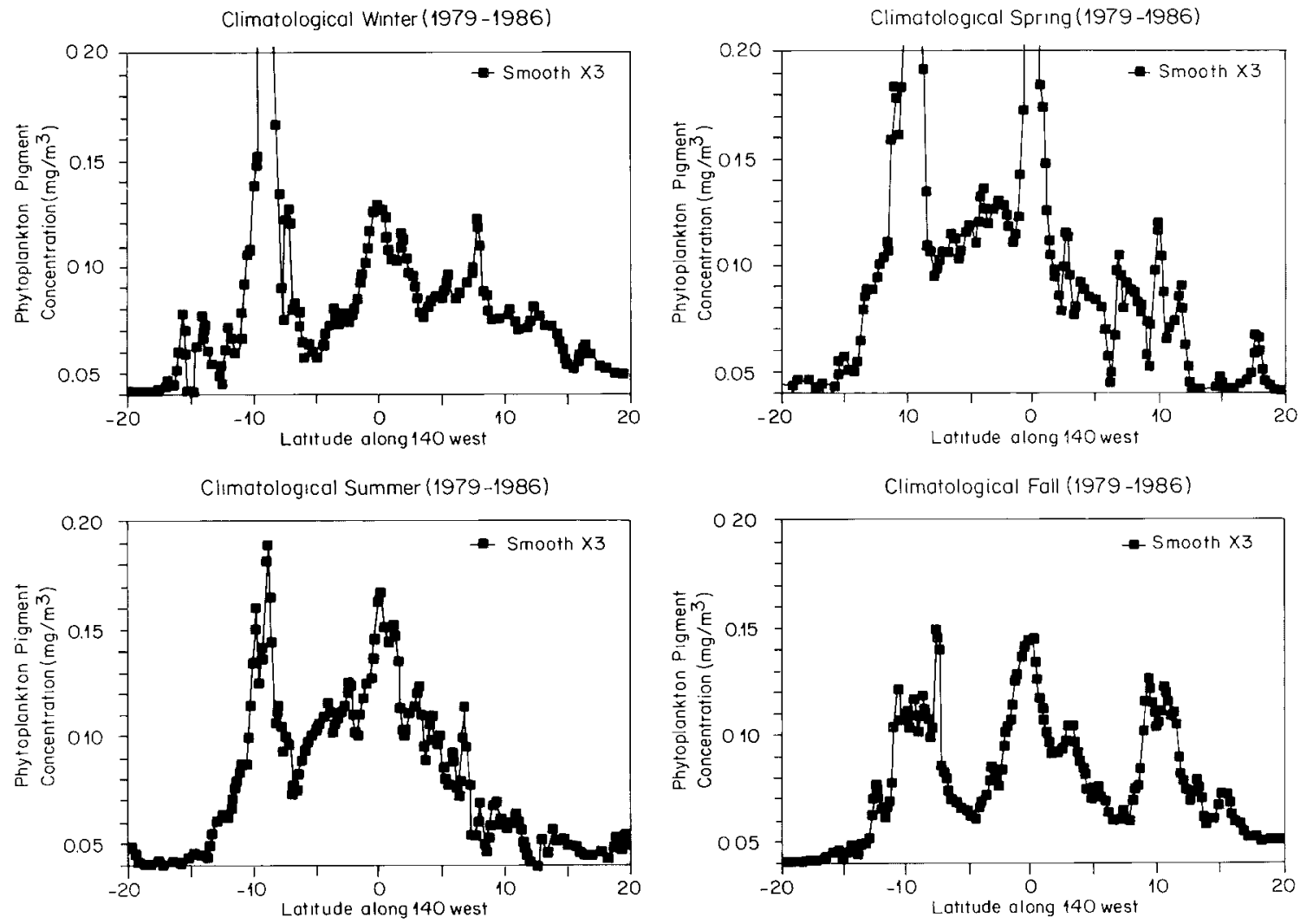

Fig. 2: Hypothetical north-south sections of total pigment across the equator $\left(20^{\circ} \mathrm{N}\right.$ to $\left.20^{\circ} \mathrm{S}\right)$ at $140^{\circ} \mathrm{W}$. The data are divided into climatological boreal winter, spring, summer, and fall data. 
terns are very similar. A measured section of chlorophyll along the equator is shown in Figure 1 of the companion article (Murray et al., 1992, this issue).

North-south sections across the equator at $140^{\circ} \mathrm{W}$ from four CZCS climatological boreal seasons are shown in Figure 2. The pigment maximum at the equator is an obvious feature. This maximum is similar in sections from $110^{\circ}$ to $150^{\circ} \mathrm{W}$ as well. There are two features that stand out in these meridional sections at $140^{\circ} \mathrm{W}$ that were utilized for EqPac planning. The first is a pigment maximum located at $10^{\circ} \mathrm{S}$ that represents a plume extending downstream from the Marquesas Islands $\left(7^{\circ}\right.$ to $11^{\circ} \mathrm{S}, 137^{\circ}$ to $\left.142^{\circ} \mathrm{W}\right)$. The plume extends $>1,000 \mathrm{~km}$ to the west of the islands (see cover) and is present in all seasons. This feature also can be seen in the section at $150^{\circ} \mathrm{W}$ (not shown), however it is farther north and of decreased magnitude. The plume is clearly associated with the Marquesas because there is no evidence of it on the upstream side (to the east at $135^{\circ} \mathrm{W}$ ). Unfortunately, there are no ship-board data available to evaluate how much of this signal is due to detrital material shed from the islands rather than to enhanced primary production associated with the islands. For this reason, the EqPac stations south of $5^{\circ} \mathrm{S}$ were moved toward $135^{\circ} \mathrm{W}$ instead of $140^{\circ} \mathrm{W}$.

The second feature utilized in EqPac planning is a divergence located along the northern edge of the north equatorial counter current (NECC), near $9-11^{\circ} \mathrm{N}$. This divergence is due to increased Ekman transport in a northward direction resulting from a strong curl in the northeast trade winds. The CZCS data suggest a pigment maximum at this latitude, possibly due to nutrients supplied by the enhanced shear and divergence. This feature is not always present but is most commonly seen in the boreal fall season. The highest pigment values at $10^{\circ} \mathrm{N}$ are in the east and the feature has disappeared by $160^{\circ} \mathrm{W}$. There is not much field data that we can use to validate the satellite observations, however, a similar distribution does appear in the calculated primary productivity map of Berger et al. (1987). It is not possible with the present data to evaluate whether this maximum is a result of local processes or is a plume of high pigment concentrations associated with high nutrient waters advected west from the upwelling region in the eastern Pacific called the Costa Rica Dome. The EqPac transect begins at $12^{\circ} \mathrm{N}$, to sample this divergence at $10^{\circ} \mathrm{N}$.

The spatial and temporal CZCS pigment data have been constructive in formulating the hypotheses for EqPac. The existing large-scale satellite ocean-color imagery was key for planning by allowing careful placing of the stations. This has been an excellent opportunity to illustrate how satellite ocean-color imagery can be used in oceanographic planning.

\section{Acknowledgements}

The support of NSF is gratefully acknowledged through grant numbers OCE9024379 (JWM) and OCE9022704 (ML). This is University of Washington Contribution Number 1940.

\section{References}

Berger, W.H., K. Fischer, C. Lai and G. Wu, 1987: Ocean productivity and organic carbon flux. SIO Reference 87-30, $67 \mathrm{pp}$.

Chavez, F.P. and R.T. Barber, 1987: An estimate of new production in the equatorial Pacific. Deep-Sea Research, 34, 1229-1243.

Feldman, G.C., 1985: Satellite Observations of Phytoplankton Variability in the Eastern Equatorial Pacific. Ph.D. dissertation, State University of New York at Stony Brook. $219 \mathrm{pp}$.

1986: Patterns of phytoplankton production around the Galapagos Islands. In: Tidal Mixing and Plankton Dinamics. Lecture Notes on Coastal and Estuarine Studies. M. Bowman, C. Yentsch and W. Peterson, eds., Springer-Verlag, 77-106.

, N.A. Kuring. C. Ng, W.E. Esaias, C.R. McClain. J.A. Elrod, N. Maynard, D. Endres, R. Evans, J. Brown, S. Walsh, M. Carle, and G. Podesta. 1989: Ocean color: availability of the global data set. EOS, 70,634-641.

Gordon. H.R. and A.Y. Morel. 1983: Remote Assessment of Ocean Color for Interpretation of Satellite Visible Imagery: Springer-Verlag. New York. $114 \mathrm{pp}$.

Leinen M. and J.W. Murray, 1990: A Rationale and Plan for US-JGOFS Ocean Flux Studies in the Central Equatorial Pacific. LS-JGOFS, 37 pp.

Murray, J.W., M. Leinen, R.A. Feely, J.R. Toggweiler and R. Wanninkhof, 1992: EqPac: A process study in the central equatorial Pacific. Oceanographts: 5, 134-142. $\square$
There are two

features . . at $140^{\circ} \mathrm{W}$

that were utilized for

EqPac planning. 